\title{
A Study on Sentinel Node and Occult Lesion Localisation: Do We Really Need an Intraoperative Frozen Examination?
}

\section{Sentinel Nod ve Okült Lezyon Lokalizasyonunda İntraoperatif Frozen Değerlendirme Gerekli midir?}

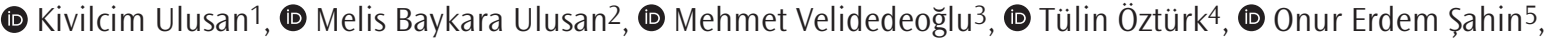 \\ (D) Sina Ferahman6, (1) Mehmet Ferahman³
}

\author{
1istanbul Training and Research Hospital, Clinic of General Surgery, Istanbul, Turkey \\ 2istanbul Training and Research Hospital, Clinic of Radiology, İstanbul, Turkey \\ 3istanbul University-Cerrahpașa, Cerrahpașa Faculty of Medicine, Department of General Surgery, İstanbul, Turkey \\ ${ }^{4}$ Istanbul University-Cerrahpașa, Cerrahpașa Faculty of Medicine, Department of Pathology, İstanbul, Turkey \\ 5 Sivas Numune Hospital, Clinic of Nuclear Medicine, Sivas, Turkey \\ 6University of Health Sciences Turkey, Bakırköy Dr. Sadi Konuk Training and Research Hospital, Clinic of General Surgery, İstanbul, Turkey
}

\begin{abstract}
Introduction: The sentinel node and occult lesion localisation (SNOLL) technique combines radio-guided occult lesion localisation and sentinel lymph node biopsy (SLNB) using radioisotopes. In addition to the success of the SNOLL procedure, we investigated the efficacy and necessity of intraoperative frozen pathology in terms of clear margins and reinterventions in non-palpable breast lesions (NPBLs).

Methods: The study was conducted at a single centre, in a general surgery clinic between 2006-2016. The medical records of 83 patients with NPBLs and negative axillae were acquired. Before surgery, patients were administered peritumoral and subdermal radionuclide tracer at the axillary region. All the patients underwent breast-conserving surgery and SLNB using a gamma probe following SNOLL.

Results: A malignancy was detected in 78 of 83 lesions. Analyses of intraoperative frozen sections showed that the surgical margins were clear in 35 (44.9\%), close in 17 (21.7\%), and involved in 26 (33.3\%) patients. Patients in the latter two groups underwent intraoperative re-excision of the tumour. On the final paraffin sections, surgical margin positivity was determined in seven (9\%) patients. Sentinel lymph nodes (SLNs) were detected successfully in 77 of 78 patients $(98.7 \%)$. The overall success rate of the SNOLL procedure was $88.5 \%$ (69/78) in patients surgically treated in a single operation. Intraoperative re-excision was beneficial in only 3 of 78 (3.8\%) patients.
\end{abstract}

Conclusion: SNOLL is a feasible, simple, and time-saving method for localising non-palpable breast cancers and SLNs. However, the contribution of margin assessment using frozen sections to the success of the method is limited.

Keywords: Sentinel lymph node, sentinel node and occult lesion localisation (SNOLL), non-palpable breast cancer, radioguided surgery, radio-guided occult lesion localisation (ROLL)

\section{öZ}

Amaç: Sentinel nod ve okült lezyon lokalizasyonu (SNOLL), radyonüklid okült lezyon lokalizasyonu ve sentinel lenf nodu biyopsisinin (SLNB) birlikte kullanıldığı tekniktir. Çalıșmamızda SNOLL işleminin başarısının yanı sıra palpe edilemeyen meme lezyonlarında cerrahi sınır pozitifliği ve tekrar girişim açısından intraoperative dondurulmuş patoloji gerekliliği ve yararlılığını da araştırdık.

Yöntemler: Çalıșma 2006-2016 yılları arasında tek merkezde genel cerrahi kliniğimizde yapılmıştır. Palpe edilemeyen meme lezyonu olan aksillası negatif 83 hastanın kayıtları kullanılmıștır. Cerrahiden önce tüm hastalara peritümoral ve aksilla bölgesinde subdermal radyonüklid enjekte edilmiştir. Tüm hastalara SNOLL prosedürünü takiben gama prob yardımı ile meme koruyucu cerrahi ve SLNB uygulanmıștır.

Bulgular: Seksen üç hastanın 78'inde malignite tespit edilmiștir. Intraoperatif dondurulmuş incelemede 35 (\%44,9) hastada cerrahi sınır negatif, 17 hastada $(\% 21,7)$ yakın cerrahi sınır ve $26(\% 33,3)$ hastada cerrahi sınır pozitif olarak gelmiștir. Son iki gruptaki hastalara intraoperatif tümör reeksizyonu yapılmıștır. Nihai paraffin incelemede 7 (\%9) hastada cerrahi sınır pozitifliği tespit edilmiștir. Sentinel lenf nodları (SLN)'ler 78 hastanın 77 'sinde $(\% 98,7)$ başarı ile tespit edilebilmiştir. Tek operasyon ile tedavi edilen hastalarda SNOLL prosedürünün genel başarısı \%88,5'tir (69/78). Intraoperatif reeksizyon hastaların sadece üçünde $(\% 3,8)$ fayda sağlamıştır.

Sonuç: SNOLL; palpe edilemeyen meme kanserlerinde ve SLN'lerin lokalizasyonunda kolay uygulanabilen, basit ve zaman kazandırıcı bir yöntemdir. Ancak dondurulmuş inceleme ile cerrahi sınır değerlendirmesinin yöntemin bașarısına olan katkısı sınırlıdır.

Anahtar Kelimeler: Sentinel lenf nodu, sentinel lenf nodu ve okült lezyon lokalizasyonu (SNOLL), non-palpabl meme kanseri, radyonüklid işaretleme, radyonüklid okült lezyon lokalizasyonu (ROLL) 


\section{Introduction}

Breast lesions detected incidentally in screening programmes without any findings in breast examinations are referred to as non-palpable breast lesions (NPBLs) (1). The incidence of malignancy in NPBL varies between $14 \%$ and $25 \%(2,3)$.The widespread use of screening programmes and imaging modalities to raise awareness about breast cancer, has increased the detection rates of early breast cancer and NPBLs $(4,5)$.

Despite all these developments in the field of breast cancer, reintervention rates still vary between $20 \%$ and $50 \%$ (6). Accurate preoperative localisation is essential to prevent secondary surgeries of NPBLs (7). So far, no localisation method has been superior to the other (7). However, the most well-known among them are wireguided localisation and radio-guided occult lesion localisation (ROLL) $(8,9)$. The ROLL technique has increasingly been used in recent years (10). In this technique, the lesion is located by injecting a radiotracer under radiological guidance and surgical excision is performed using a handheld gamma probe.

In patients with non-palpable early breast cancer, the pathological state of the axillary lymph nodes (ALNS) is the most important determinant of staging, prognosis and the need for adjuvant therapy. Imaging techniques may show ALN involvement, but are inadequate for detecting micrometastases. Therefore, the sentinel lymh node (SLN) should be excised and examined histopathologically by SLN biopsy (SLNB).

The sentinel node and occult lesion localisation (SNOLL) technique combines ROLL and SLNB using radioisotopes. Many studies are investigating the success of the SNOLL technique (11-15). In addition to these, we investigated the efficacy and necessity of intraoperative frozen pathology in terms of clear margins and reinterventions in NPBLs from a screened population.

\section{Methods}

\section{Prediagnostic Work-up/Demographics}

At our general surgery clinic, 83 consecutive patients with NPBL detected by mammography, ultrasonography or magnetic resonance imaging (MRI) and treated using the SNOLL procedure between 2006 and 2016 were included in the study. All the patients underwent preoperative histological examination with either ultrasound-guided core needle biopsy or stereotactic biopsy. Six patients with benign biopsy results but high radiological suspicion were also included.

One patient with postoperatively proven fibroadenoma (included because of high radiological suspicion), two with complete disappearance of the lesion after neoadjuvant chemotherapy, one with a completely resected tumour after core biopsy and one in whom diffusion of the radiotracer into the ductus occurred and wire-guided localisation was performed were excluded. Thus, 78 patients were finally included. All the patients had clinically and radiologically negative ALNs (Figure 1).

\section{Sentinel Node and Occult Lesion Localisation Procedure}

All the patients were injected with 17.5-37 MBq 99mTc-labelled human albumin macroaggregate (MAA) (TechneScan MAA, Mallinckrodt Inc.,
St. Louis, MO, United States) intratumorally in $0.2-0.5 \mathrm{~mL}$ saline one day before surgery or on the morning of the procedure. Injections were performed by experienced breast radiologists under ultrasound, mammography or MRI guidance. In mammography-detectable masses, $0.2 \mathrm{~mL}$ radiopaque contrast material (Omnipaque; GE Healthcare, Chicago, IL, United States) was administered immediately after the radiopharmaceutical injection. The contrast covering the lesion detected by standard two-view mammography confirmed the injection of the contrast agent at the correct site. The injection was given in all the remaining cases under direct visualisation via ultrasound following the detection of changes in the lesion.

SLN detection was performed using a total of $0.2 \mathrm{~mL} 99 \mathrm{mTc}$-labelled nanocolloid radiopharmaceutical (Nanocis; CIS Bio International, Gif-sur-Yvette, France) (55.5-74 MBq) at the same time as the ROLL procedure. $99 \mathrm{mTc}$-labelled nanocolloid was injected into the periareolar region subdermally in all four quadrants $(0.05 \mathrm{~mL}$ per quadrant) by a radiologist. Preoperative scintigraphy was not routinely performed.

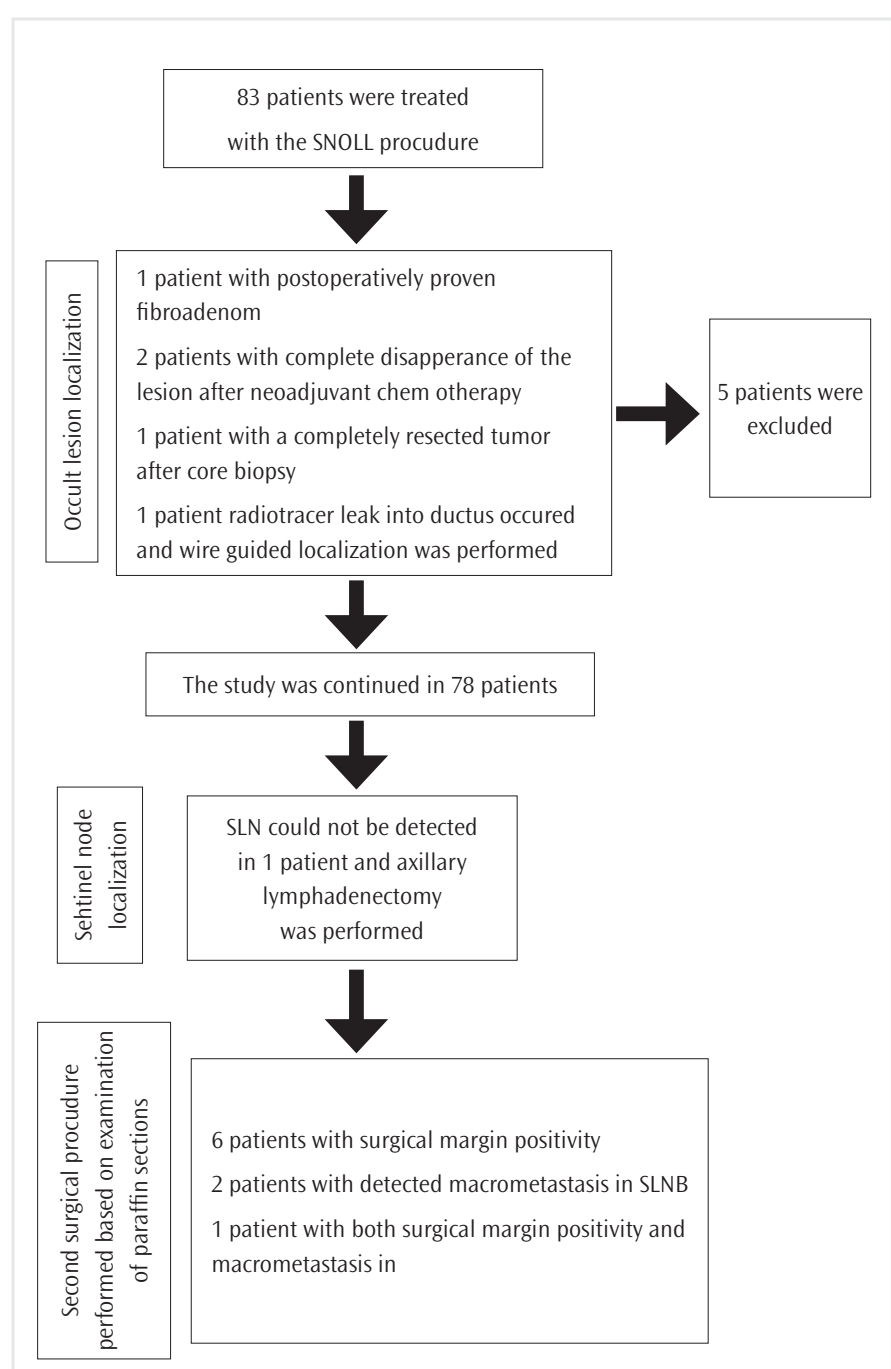

Figure 1. Study flow chart

SNOLL: Sentinel node and occult lesion localisation, SLN: sentinel lymph node, SLNB: sentinel lymph node biopsy 


\section{Surgical Procedure}

A gamma probe (First Sensor; Wake Medical, Barnsley, UK and Europrobe; Eurorad, Eckbolsheim, France) was used to determine the localisation with the highest activity and the projection of the skin was marked with a pen before general anaesthesia in the operating room. After general anaesthesia, a total of $5 \mathrm{~mL}$ patent blue dye (Blumet; VEM, İstanbul, Turkey) was applied using a $3 \mathrm{~mL}$ periareolar injection and 2 $\mathrm{mL}$ subdermal injection into the upper outer quadrant by the surgeon. The SLNB procedure was started after 5 minute of breast massage to increase lymphatic drainage.

SLNB was attempted during the same procedure with breast surgery through a separate incision over the axillary region. The criteria for removing sentinel nodes were being hot and/or blue. Clinically suspicious LNs (palpable and firm) that were neither hot nor blue were also removed. The LNs were grouped as hot, blue and palpable, and cut into frozen sections. Patients with positive SLNB results underwent immediate axillary lymph node dissection (ALND).

For excision of the primary lesion, the skin incision was guided by the gamma probe and the radioactive area was removed. The excision was performed with the aim of a free surgical margin around the tumour bed. After excision, the remaining breast tissue was checked for further radioactivity with the gamma probe. The specimen was oriented with clips and silk sutures. If microcalcifications were present in the lesion, the specimen was X-rayed (using mammography to verify that all had been removed.) All specimens were frozen and sent to the pathology laboratory.

\section{Pathology}

To determine the pathological tumour size, the largest contiguous dimension of the tumour was taken and the pathological tumour volume and total specimen volume were calculated as the height $\times$ width $\times$ length. Patients were grouped as clear or close/involved margin according to the margin status. Margin status was defined as follows: (i) clear when at least $5 \mathrm{~mm}$ of normal breast tissue surrounded the carcinoma, (ii) close when less than $5 \mathrm{~mm}$ of normal breast tissue was found and (iii) involved when invasive carcinoma was at an inked margin. Involved and close margin patients were considered positive and intraoperative re-excision was performed. Due to differences in the breast volumes of patients and the different surgeons involved in the study, standardisation of the clear margin requiring re-excision could not be performed. All excision and re-excision materials were embedded in paraffin sections and examined with standard hematoxylin and eosin staining for the final margin evaluation.

Frozen sections of all the SLNs were analysed. According to $7^{\text {th }}$ TNM staging, metastatic deposits measuring $>2 \mathrm{~mm}$ were considered macrometastases, those from $0.2 \mathrm{~mm}$ to $2 \mathrm{~mm}$ were considered micrometastases and those $<0.2 \mathrm{~mm}$ were considered isolated tumour cells (16). Patients with macrometastases underwent ALND.

\section{Statistical Analyses}

Baseline preoperative variables were compared via $\chi^{2}$ analyses or Fisher's exact test for categorical data, where appropriate. The Mann-
Whitney $\mathrm{U}$ test was used to compare the medians of nonparametric variables. Student's t test was used to compare parametric data between two independent groups provided that the distribution of data was normal. In all analyses, $p<0.05$ was considered statistically significant. Statistical analyses were performed using SPSS Statistics for Windows (Version 21.0; IBM, Armonk, NY).

\section{Ethics}

Written informed consent was obtained from each subject following a detailed explanation of the objectives and protocol of the study. The study was approved by the Medical Ethics Committee of İstanbul University-Cerrahpaşa, Cerrahpaşa Faculty of Medicine (protocol no:83045809-604.01.02, date: 12.07.2016) and was performed in accordance with the Declaration of Helsinki.

\section{Results}

Seventy-eight female patients who underwent the SNOLL procedure between 2006 and 2016 were included in the study. The mean age of the patients was $53 \pm 8.9$ years.

Of the 78 lesions detected, 48 (61.5\%) were located in the upper outer quadrant. While $68(87.2 \%)$ of the NPBLs were detected by ultrasound, $6(7.7 \%)$ and $4(5.1 \%)$ were detected by mammography and MRI, respectively. Invasive ductal carcinoma (IDC) was found in 57 (73.1\%) patients in the preoperative histopathological diagnosis. Detailed demographic data are shown in Table 1.

The largest contiguous dimension of the tumour was taken as the pathological tumour size, and the median tumour size was $1.25 \mathrm{~cm}$ (range 0.6-6.5 cm). Pathological tumour volume and total specimen volume were $1.2 \mathrm{~cm}^{3}$ (range $0.08-130 \mathrm{~cm}^{3}$ ) and $140 \mathrm{~cm}^{3}$ (range 29.7$\left.1,174 \mathrm{~cm}^{3}\right)$, respectively. The mean weights of the tumour specimens were not reported in all the cases.

According to the TNM classification, 5 (6.4\%) patients were classified as Tis, 27 (34.6\%) as T1b, $38(48.7 \%)$ as T1c, 7 (9\%) as T2 and 1 (1.3\%) as T3. Of these patients, 14 (17.9\%), 42 (53.8\%) and 20 (25.6\%) had lowgrade, intermediate-grade and high-grade tumours, respectively. At the final pathological examination, IDC was detected in 60 (76.9\%) patients, while 8 (10.3\%) patients had mixed type (invasive ductal + invasive lobular) carcinoma. The diagnoses of the remaining patients are shown in Table 2 along with the other histopathological data. Histopathological examination of the surgical specimen revealed lymphatic invasion of the tumour in 14 (17.9\%) patients.

Analyses of intraoperative frozen sections showed that surgical margins were clear $(>5 \mathrm{~mm})$ in $35(44.9 \%)$, close $(<5 \mathrm{~mm})$ in $17(21.7 \%)$ and involved in 26 (33.3\%) cases (Figure 2). Patients with close and involved margins (43 patients, 55.1\%) underwent intraoperative re-excision.

Paraffin evaluation of 43 re-excised patients showed that:

- Three patients had tumours in the re-excision specimens, but no paraffin border positivity was detected in the total (main + re-excised) specimen (Figure 2, group A).

- Thirty five patients had no tumours in the re-excision specimens (Figure 2, group B). 
- Three patients had no tumours in the re-excision specimens, but the main specimen showed paraffin border positivity (Figure 2, group C).

- Two patients had tumours in the re-excision specimens and showed paraffin border positivity (Figure 2, group D).

Group A and B together formed the clear margin group according to the final paraffin examination. This group did not undergo a secondary surgical procedure. Since group C and D showed margin positivity in the total material, they constituted the involved margin group.

On paraffin evaluation of 35 patients who were clear according to the intraoperative frozen section:

- Two patients showed paraffin border positivity (Figure 2, group E).

\section{Table 1. Demographical data of patients}

\begin{tabular}{|c|c|}
\hline Patients & $n=78(100 \%)$ \\
\hline Mean age (years) & $53 \pm 8.9$ \\
\hline \multicolumn{2}{|l|}{ Menopausal status } \\
\hline Postmenopausal & 44 (56.4\%) \\
\hline Premenopausal & $34(43.6 \%)$ \\
\hline \multicolumn{2}{|l|}{ Referral source } \\
\hline Routine screening & $40(51.3 \%)$ \\
\hline Symptomatic & $26(33.3 \%)$ \\
\hline Cancer follow-up & $12(15.4 \%)$ \\
\hline \multicolumn{2}{|l|}{ Family history } \\
\hline No & $53(67.9 \%)$ \\
\hline Yes & 25 (32.1\%) \\
\hline \multicolumn{2}{|l|}{ Primary cancer side } \\
\hline Left & $40(51.3 \%)$ \\
\hline Right & $38(48.7 \%)$ \\
\hline \multicolumn{2}{|l|}{ Tumor location } \\
\hline Upper lateral & $48(61.5 \%)$ \\
\hline Lower lateral & $10(12.8 \%)$ \\
\hline Upper medial & $8(10.3 \%)$ \\
\hline Lower medial & $6(7.7 \%)$ \\
\hline Retroareolar & $6(7.7 \%)$ \\
\hline \multicolumn{2}{|l|}{ Radiological feature } \\
\hline Mass & $73(93.6 \%)$ \\
\hline Microcalcifications & $3(3.8 \%)$ \\
\hline Stromal asymmetry & $2(2.6 \%)$ \\
\hline \multicolumn{2}{|c|}{ Preoperative tumor histology } \\
\hline Invasive ductal & $57(73.1 \%)$ \\
\hline Mixed type & $4(5.1 \%)$ \\
\hline In situ carcinoma & $3(3.8 \%)$ \\
\hline Tubular carcinoma & $3(3.8 \%)$ \\
\hline Invasive lobular & $2(2.6 \%)$ \\
\hline Mucinous carcinoma & $2(2.6 \%)$ \\
\hline Papillary carcinoma & $1(1.3 \%)$ \\
\hline Biopsy not malignant** & $6(7.7 \%)$ \\
\hline
\end{tabular}

- Thirty three patients were also clear on paraffin evaluation and showed no border positivity (Figure 2, group F).

Taken together, examination of paraffin sections to determine the final margin status revealed surgical margin positivity in seven (9\%) patients (Figure 2, group $\mathrm{C}+\mathrm{D}+\mathrm{E}$ ). A second surgical procedure was performed in these patients. There were no significant differences in terms of paraffin border positivity or secondary surgery rates between patients with intraoperative re-excision based on pathology.

The overall success of SLN detection was $98.7 \%$ (77/78 patients). The mean number of SLNs per case was 2.39 (range 1-5). A total of 178 LNs were harvested from 77 patients because they were hot $(n=26)$, blue $(n=9)$, or hot and blue $(n=127)$. Sixteen non-hot non-blue (non-sentinel) LNs were also removed because of a high clinical suspicion (i.e., firm upon palpation). Axillary lymphadenectomy was performed in 12 patients because the LN was metastatic (hot + blue, $n=10$; hot, $n=1$; palpable, $n=1$ ) (Table 3).

According to the TNM classification, the positive SN was present in 15 (21.8\%) cases (macrometastases, $n=12$; micrometastases, $n=3$ and isolated tumour cells, $n=2$ ). In addition, two more axillary lymphadenectomies were performed because the SLN could not be detected in one case and the second was according to the surgeon's preference, although the patient had micrometastases (during initial surgery, $n=11$; after paraffin section examination, $n=3$ ) (Table 4).

As the results were evaluated together, the success of the SNOLL procedure was $88.5 \%(69 / 78)$ in patients surgically treated in a single operation. Nine patients underwent supplementary surgery, including

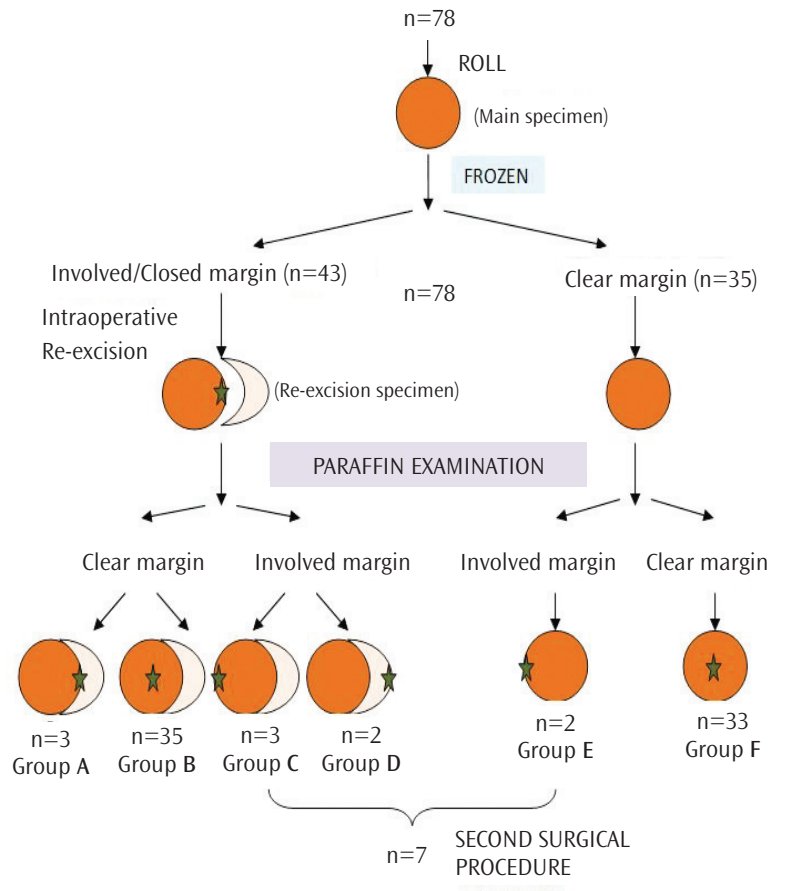

Figure 2: Pathological examination chart. symbol indicates the main/ first excision specimen. ( symbol indicates the re-excision specimen. * symbol indicates the tumor

ROLL: Radio-guided occult lesion localisation 
breast resection in six cases, ALND in two cases and both surgical procedures in one case (Table 2).

\section{Table 2. Tumor characteristics and margin status}

\section{Patient}

Histopathological tumor size

$<2 \mathrm{~cm} / 22 \mathrm{~cm}$

Tumor volume

Total specimen volume

T category of tumor

Tis

$\mathrm{T} 1 \mathrm{~b}$

T1c

$\mathrm{T} 2$

$\mathrm{T} 3$

\section{Postoperative tumor histology}

Invasive ductal

Mixed type

In situ carcinoma

Tubular carcinoma

Invasive lobular

Mucinous carcinoma

Papillary carcinoma

Neuroendocrine tumor

\section{Lymphatic invasion}

Yes

No

Margin status (Frozen section)

Involved

Close margin

$1 \mathrm{~mm}$

$2 \mathrm{~mm}$

$3 \mathrm{~mm}$

$4 \mathrm{~mm}$

$5 \mathrm{~mm}$

Clear margin

Margin status (Paraffin exam)

Involved

$<1 \mathrm{~cm}$ not involved

$\geq 1 \mathrm{~cm}$ clear

Reoperation

Margin positivity

SLN positivity

Margin + SLN positivity

Med: Median, SLN: sentinel lymph node $n=78$

Med: $1.25 \mathrm{~cm}$ (minimum: 0.6

$\mathrm{cm}$, maximum: $6.5 \mathrm{~cm})$

$63(80.8 \%) / 15$ (19.2\%)

Med: $1.2 \mathrm{~cm}^{3}$ (minimum: 0.08 $\mathrm{cm}^{3}$, maximum: $130 \mathrm{~cm}^{3}$ )

Med: $140 \mathrm{~cm}^{3}$ (minimum: 29.7 $\mathrm{cm}^{3}$, maximum: $\left.1,174 \mathrm{~cm}^{3}\right)$

$5(6.4 \%)$

$27(34.6 \%)$

$38(48.7 \%)$

$7(9 \%)$

1 (1.3\%)

$60(76.9 \%)$

$8(10.3 \%)$

$4(5.1 \%)$

2 (2.6\%)

$1(1.3 \%)$

1 (1.3\%)

1 (1.3\%)

$1(1.3 \%)$

14 (17.9\%)

64 (82.1\%)

$26(33.3 \%)$

17 (21.8\%)

7 (9\%)

$3(3.8 \%)$

$3(3.8 \%)$

0 (0\%)

4 (5.1\%)

35 (44.9\%)

\section{7 (9\%)}

25 (32\%)

46 (59\%)

$9(11.5 \%)$

$6(7.7 \%)$

$2(2.6 \%)$

$1(1.3 \%)$

Total specimen volumes were significantly higher in patients without intraoperative re-excision $(p=0.046)$. No significant correlation was found between any other parameters and intraoperative re-excision (Table 5).

\section{Discussion}

The SNOLL technique has become an accepted surgical technique for the excision of NPBLs. Although there have been many improvements in this technique, including SLNB with excision of the breast lesion, there are still different methods with regard to the use of a localisation agent (blue dye, radiotracer or both), location of the injection (periareolar, peritumoral, subareolar), timing of localisation and the axillary approach after examination of the removed LNs (17).

In recent studies, the re-excision criterion for IDC was determined as "no ink on tumour" $(18,19)$. Due to differences in the breast volumes of patients and the different surgeons involved in the study, standardisation

Table 3. Sentinel node intraoperative findings

\begin{tabular}{|l|l|l|l|}
\hline & SLN (-) & SLN $(+)$ & Total \\
\hline Hot & 25 & 1 & 26 \\
\hline Blue & 9 & 0 & 9 \\
\hline Palpable & 15 & 1 & 16 \\
\hline Hot + blue & 117 & 10 & 127 \\
\hline Total & 166 & 12 & 178 \\
\hline SLN:sentinel lymph node & & & \\
\hline
\end{tabular}

Table 4. Sentinel node biopsy pathological results

$$
\begin{array}{|l|}
\hline \text { Pa } \\
\hline \text { Su } \\
\hline \text { Nu } \\
\hline 0 \\
\hline 1 \\
\hline 2 \\
\hline 3 \\
\hline 4 \\
\hline 5 \\
\hline
\end{array}
$$

\begin{tabular}{l} 
Patie \\
\hline Succ \\
\hline 0 \\
1 \\
\hline 2 \\
\hline 3 \\
\hline 4 \\
\hline 5
\end{tabular}

Patients

Success of SLN detection

Number of SLN

$\mathrm{N}$ category of SLN

NO

NO (i+)

N1mi

N1a

Axillary dissection

With frozen section

With paraffin exam

SLN not found

$n=78(100 \%)$

77 (98.7\%)

Mean: $2.39 \pm 0.14$

$1(1.3 \%)$

$20(25.6 \%)$

31 (39.7\%)

$14(17.9 \%)$

$6(7.7 \%)$

$6(7.7 \%)$

SLN: sentinel lymph node, N0 (i+): isolated tumour cells, N1mi: micrometastases, N1a: macrometastases 
of the clear margin requiring re-excision could not be performed. When cases were evaluated retrospectively, the maximum clear margin limit for re-excision was $5 \mathrm{~mm}$. Margin groups were defined according to this limit. As margin positivity and reoperation rates are higher for ductal carcinoma in situ (DCIS), excision is performed with a wider border (20). Although it is not appropriate to evaluate IDC and DCIS patients together, our cohort included only four DCIS patients among 78 patients and it did not affect the statistics. In contrast, none of the DCIS patients in our study required re-excision or reoperation.

ALN involvement is still one of the most important prognostic factors in breast cancer and affects disease-free survival (11). The rate of SLN detection in our study was $98.7 \%$, similar to previous studies that have used a combined radiotracer and blue dye technique (11-13). Besic et al. (21) reported a 93\% SLN detection rate with the combined technique. They concluded that the lower rate was because a higher proportion of patients had hematoma due to the preoperative biopsy (21). We had better results although all of the patients underwent preoperative fine needle aspiration biopsy.

There are different opinions about the use of the combined technique for the detection of SLN. In our study, all blue nodes were also hot; therefore, the need to use blue dye can be questioned. However, the use of blue dye has been reported to increase the SN detection rate $(11,22,23)$. Suspected palpable LNs should also be excised during the surgery. LN involvement may not be seen if the LNs are obstructed by tumour metastases (14). In our study, macrometastasis was detected in one of the non-hot non-blue nodes that were removed as palpable. Until recently, ALND was accepted as the gold standard for all patients with macrometastases in SLN and a large proportion of patients with micrometastases. Recent studies have been carried out on patients with micrometastasis in the SLN and followed-up without axillary dissection. The results of the most important randomised study in $\mathrm{SLN}^{+}$patients were reported in 2017 (24). In the 10-year follow-up period, there were no significant differences in locoregional recurrence in groups with and without dissection. The American College of Surgeons Oncology Group Z11 study showed that the common opinion that axillary dissection with adjuvant treatment protocols increases life expectancy is incorrect (24). Although there was insufficient data to predict survival in our study, axillary dissection was not necessary. Non-sentinel LNs were positive in only 2 of 14 patients who underwent ALND in our study. The remaining 12 patients did not have extra-SLN involvement.

The need for intraoperative excision to obtain maximum benefits with minimum tissue loss is controversial. Many authors have argued that analysing frozen sections is insufficient for detecting the negative surgical margin of non-palpable lesions due to high false-negative rates $(15,21,25,26)$. In some cases in our study, definitive surgery for invasive carcinoma was performed with a single operation, but it did not affect the number of reoperations. Forty-three patients underwent intraoperative re-excision because frozen sections showed involved or close margins. Of these patients, $38 \mathrm{did}$ not benefit from re-excision (group $\mathrm{B}+\mathrm{C}$ ). Two of them showed margin positivity on paraffin

Table 5. Effect of demographic and pathological parameters on intraoperative re-excision

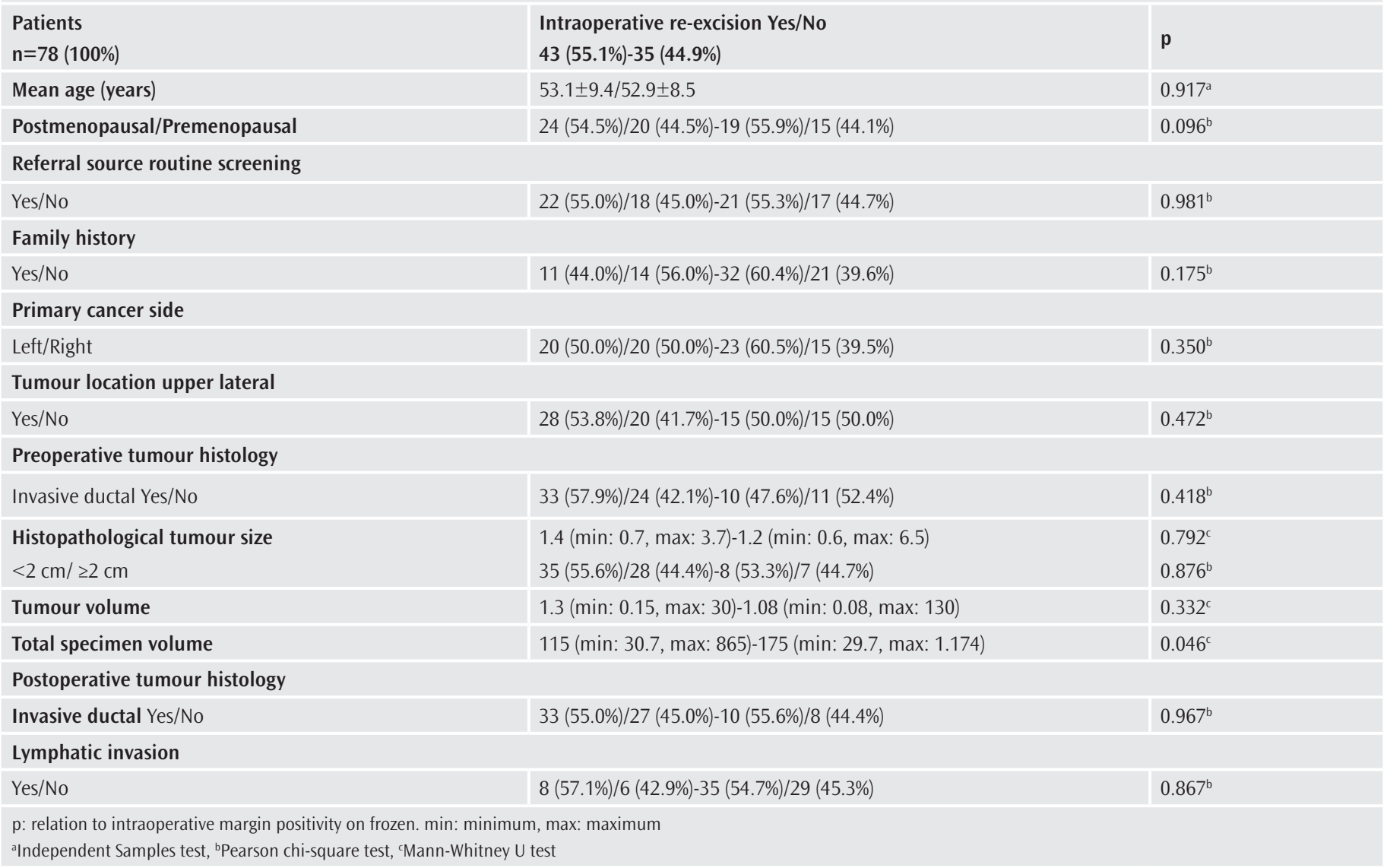


examination (group D). Although these patients seemed to benefit from frozen examination, frozen section could not prevent secondary surgery in this group. Intraoperative re-excision was beneficial in only 3 of 78 (3.8\%) patients (group A) (Figure 2).

The success of intraoperative frozen section is to prevent the patient from undergoing a secondary surgery. Therefore, we think that it is not necessary to perform intraoperative re-excision based on examinations of frozen sections.

In a similar previous study, the factors affecting the involvement of the surgical margin included patient age $>50$ years, radiological tumour size $>20 \mathrm{~mm}$, surgical specimen $\geq 50 \mathrm{~g}$ and invasive ductal type carcinoma (21). In our study, there were also significant relationships between margin positivity and postoperative diagnosis of IDC and tumour size $\geq 20 \mathrm{~mm}$.

Achieving high success rates with a single surgery, easier localisation for radiologists and surgeons, less discomfort for patients, shorter marking time and better cosmetic appearance are important advantages of the SNOLL technique (27). If the success of the SNOLL procedure is considered cure with a single surgical operation, the success rate was $88.5 \%$ in our study. A total of nine (11.5\%) patients required a second surgery due to margin positivity and/or SLN positivity.

The technique also has some disadvantages, including the need for multidisciplinary work, the presence of a nuclear medicine unit, wrong injection of radionuclide material, radionuclide leakage to the duct and the need for probes $(11,13)$. In the present study, the lesions were easily marked by ROLL in all except one patient with leakage of the radiotracer into the neighbouring ductus. This lesion was localised by wire-guided localisation and excised. In postoperative follow-up, one patient developed hematoma and two patients developed abscesses. One patient undergoing axillary dissection developed movement limitation and paraesthesia in the arm.

\section{Study Limitations}

This study was limited by its retrospective nature. In addition, as six different surgeons participated in the study, this may have caused small differences in the surgical procedure. As a 10-year period was retrospectively reviewed in this study, and changes in clinical and pathological approaches, surgical experience and guidelines vary over time, this may have affected our results.

\section{Conclusion}

SNOLL is a readily applicable and reliable method for localising nonpalpable breast cancers and SLNS. The development of this technique aims to achieve better results with less tissue loss. Although the contribution of margin assessment of frozen sections to the success of the method is limited, further studies on larger populations are needed.

\section{Ethics}

Ethics Committee Approval: The study was approved by the Medical Ethics Committee of İstanbul University-Cerrahpașa, Cerrahpaşa Faculty of Medicine (protocol no:83045809-604.01.02, date: 12.07.2016).
Informed Consent: Written informed consent was obtained from all patients

Peer-review: Externally and internally peer-reviewed.

Authorship Contributions: Surgical and Medical Practices - K.U., M.V., O.E.S., S.F., M.F. ; Concept - K.U. ; Design - K.U., M.B.U. ; Data Collection or Processing - K.U., M.B.U., O.E.Ş. ; Analysis or Interpretation - K.U., M.B.U., M.V., T.Ö., M.F. ; Literature Search - K.U., M.B.U., M.V., T.Ö., O.E.S., S.F. ; Writing - K.U., M.B.U., M.V., T.Ö., O.E.Ș., S.F.

Conflict of Interest: No conflict of interest was declared by the authors.

Financial Disclosure: The authors declared that this study received no financial support.

\section{References}

1. Veronesi U, Luini A, Botteri E, Zurrida S, Monti S, Galimberti V, et al Nonpalpable Breast Carcinomas: Long-Term Evaluation of 1,258 Cases. Oncologist 2010; 15: 1248-52.

2. De Cicco C, Pizzamiglio M, Trifirò G, Luini A, Ferrari M, Prisco G, et al Radioguided occult lesion localisation (ROLL) and surgical biopsy in breast cancer. Technical aspects. Q J Nucl Med 2002; 46: 145-51.

3. Ernst MF, Roukema JA. Diagnosis of non-palpable breast cancer: a review. Breast 2002; 11: 13-22.

4. Park SY, Kim HJ, Kim WH, Cheon HJ, Lee H, Park HY, et al. Feasibility of ultrasound-guided absorbable retaining thread needle localization for nonpalpable breast lesions. Ultrasonography 2019; 38: 272.

5. Follacchio GA, Monteleone F, Anibaldi P, De Vincentis G, lacobelli S, Merola $\mathrm{R}$, et al. A modified sentinel node and occult lesion localization (SNOLL) technique in non-palpable breast cancer: a pilot study. J Exp Clin Cancer Res 2015; 34: 113.

6. Corsi F, Bossi D, Combi F, Papadopoulou O, Amadori R, Regolo L, et al. Radioguided vs clip-guided localization of nonpalpable mass-like lesions of the breast from a screened population: A propensity score-matched study. J Surg Oncol 2019; 119: 916-24.

7. Chan BK, Wiseberg-Firtell JA, Jois RH, Jensen K, Audisio RA. Localization techniques for guided surgical excision of non-palpable breast lesions. Cochrane Database Syst Rev 2015; CD009206.

8. della Rovere GQ, Benson JR, Morgan M, Warren R, Patel A. Localization of impalpable breast lesions--a surgical approach. Eur J Surg Oncol 1996; 22 : 478-82.

9. Aljohani B, Jumaa K, Kornecki A, Brackstone M. Clinical utility of radioactive seed localization in nonpalpable breast cancer: $A$ retrospective single institutional cohort study. Int J Surg 2018; 60: 149-52.

10. Paganelli G, Luini A, Veronesi U. Radioguided occult lesion localization (ROLL) in breast cancer: maximizing efficacy, minimizing mutilation. Ann Oncol 2002; 13: 1839-40.

11. Thind CR, Tan S, Desmond S, Harris O, Ramesh HSJ, Chagla L, et al. SNOLL. Sentinel node and occult (impalpable) lesion localization in breast cancer. Clin Radiol 2011; 66: 833-9.

12. Lavoué V, Nos C, Clough KB, Baghaie F, Zerbib E, Poulet B, et al. Simplified technique of radioguided occult lesion localization (ROLL) plus sentinel lymph node biopsy (SNOLL) in breast carcinoma. Ann Surg Oncol 2008; 15: 2556-61.

13. Giacalone PL, Bourdon A, Trinh PD, Taourel P, Rathat G, Sainmont M, et al Radioguided occult lesion localization plus sentinel node biopsy (SNOLL) versus wire-guided localization plus sentinel node detection: A case control study of 129 unifocal pure invasive non-palpable breast cancers. Eur J Surg Oncol 2012; 38: 222-9.

14. Ahmed M, Douek M. Sentinel node and occult lesion localization (SNOLL): A systematic review. Breast 2013; 22: 1034-40. 
15. Barros AC, Barros MA, Andrade FE, Mori LJ, Costa PA, Sheng PY, et al. Combined radioguided nonpalpable lesion localization and sentinel lymph node biopsy for early breast carcinoma. Ann Surg Oncol 2007; 14: 1472-7.

16. Edge SB, Compton CC. The american joint committee on cancer: the 7th edition of the AJCC cancer staging manual and the future of TNM. Ann Surg Oncol 2010; 17: 1471-4.

17. Çelik V, Aydogan F, Yılmaz MH. Non-palpabl lezyonlara yaklașım. Özmen V, editor. Meme Hastalıkları Kitabı. Ankara: Güneș Tıp Kitabevleri; 2012.p.34550.

18. Pilewskie M, Morrow M. Margins in breast cancer: How much is enough?. Cancer 2018; 124: 1335-41.

19. Houssami N, Macaskill P, Marinovich ML, Morrow M. The association of surgical margins and local recurrence in women with early-stage invasive breast cancer treated with breast-conserving therapy: a meta-analysis. Ann Surg Oncol 2014; 21: 717-30.

20. Laws A, Brar MS, Bouchard-Fortier A, Leong B, Quan ML. Does intra-operative margin assessment improve margin status and re-excision rates? A populationbased analysis of outcomes in breast-conserving surgery for ductal carcinoma in situ. J Surg Oncol 2018; 118: 1205-11.

21. Besic N, Kramaric A, Podnar B, Perhavec A, Music M, Grazio-Frkovic S, et al. Factors correlated to successful surgical treatment of 181 non-palpable invasive breast carcinomas. Breast 2009; 18: 294-8.
22. Straver ME, Meijnen P, van Tienhoven G, van de Velde CJH, Mansel RE, Bogaerts $\mathrm{J}$, et al. Sentinel node identification rate and nodal involvement in the EORTC 10981-22023 AMAROS trial. Ann Surg Oncol 2010; 17: 1854-61.

23. Rodier J-F, Velten M, Wilt M, Martel P, Ferron G, Vaini-Elies V, et al. Prospective multicentric randomized study comparing periareolar and peritumoral injection of radiotracer and blue dye for the detection of sentinel lymph node in breast sparing procedures: FRANSENODE trial. J Clin Oncol 2007; 25: 3664-9.

24. Giuliano AE, Ballman KV, McCall L, Beitsch PD, Brennan MB, Kelemen PR, et al. Effect of axillary dissection vs no axillary dissection on 10-year overall survival among women with invasive breast cancer and sentinel node metastasis: The ACOSOG Z0011 (Alliance) Randomized Clinical Trial. JAMA 2017; 318: 918.

25. Cendán JC, Coco D, Copeland EM. Accuracy of intraoperative frozen-section analysis of breast cancer lumpectomy-bed margins. J Am Coll Surg 2005; 201: 194-8.

26. Osborn JB, Keeney GL, Jakub JW, Degnim AC, Boughey JC. Cost-effectiveness analysis of routine frozen-section analysis of breast margins compared with reoperation for positive margins. Ann Surg Oncol 2011; 18: 3204-9.

27. Rampaul RS, Bagnall M, Burrell H, Pinder SE, Evans AJ, Macmillan RD. Randomized clinical trial comparing radioisotope occult lesion localization and wire-guided excision for biopsy of occult breast lesions. Br J Surg 2004; 91: 1575-7. 